health issues are. The challenge to any government is how to respond to them.

To have reached this point is in itself a major achievement. If one party had run away with the Health for All ball we would have been faced with the usual British nonsense whereby good ideas are opposed just because the other party thought of them first. Something of this has been evident in the Labour party's response to the green paper and in what could be an interminable argument about who has stolen whose clothes. Such argument is a diversion; to a large extent they are WHO's clothes anyway, and the former director general, Halfdan Mahler, and the current European director, Jo Asvall, have a right to some of the credit. So too does the current chief medical officer, Sir Donald Acheson, whose hand is in there somewhere. At present the Labour party is attacking the wrong goal, and if it wins the next election it is likely to be more than happy to base its policy on the green paper. What it should be concentrating on now is the government's continuing weakness - the level of NHS funding and the mechanisms of accountability.

Those who have criticised the green paper for not going far enough are overlooking the effect of having an explicit document from which there can be no going back. The policies listed in the future election manifestos of all the political parties will be judged by their likely success at solving the problems acknowledged in The Health of the Nation.

Head of Department, Department of Public Health, JOHN ASHTON

University of Liverpool,

Liverpool L69 3BX

World Health Organisation Almu Ata 1978 Primary heulth care Geneva: WHO, 1978.

World Health Organisation. Global strategy for health for all by the vear 2000. Geneva: WHO, 1981

Secretary of State for Health. The health of the nation: a consultatize document for health in England. London, HASO): 1991. (Cm 1523.)

4 Delamothe T. Health manifestos: the government. BMY 1991:302:1355-6.

Dillner L. Health manifestos: Labour. BMF 1991:302:1356.

6 Ashton J. Sanitarian becomes ecologist; the new environmental health. BMF 1991;302:189-90. Lalonde M. A new perspective on the health of Canadians. Ottawa: Minister of Supply and Services, 1974

8 Ashton J. Health in Mersey, a review. Liverpool: Department of Public Health, University of Liverpool, 1974.

9 Ashton J, Sevmour H. The new public health. Milton Kevnes: Open University Press: 1988. 10 Ashton J. Tying down indicators and targets for health for all. Community Health Studies 1988:12:376-85

11 Catford JC. Health targets. B.M7 1991;302:980-1.

\title{
The daughters of stilboestrol
}

\author{
Grown up now but still at risk
}

Stilboestrol (diethylstilbestrol, DES) is a synthetic nonsteroidal oestrogen, first described in $1938^{\circ}$ and promoted in the late 1940s for preventing miscarriages and preterm births. ${ }^{2}$ In 1971 an association was reported between in utero exposure to stilboestrol and the subsequent development of clear cell adenocarcinoma of the vagina in young women. ${ }^{3+}$ The use of stilboestrol in pregnancy was prohibited in the United States that year. In 1973 the Committee on Safety of Medicines in the United Kingdom advised against the use of stilboestrol in pregnancy. An estimated two to three million American women received stilboestrol during pregnancy. ${ }^{5} \mathrm{~A}$ postal survey in 1974 suggested that 7500 women had received the drug in Britain, mostly during the 1950 s. $^{6}$

Further study of the daughters of women who received the drug in pregnancy led to the recognition of various teratogenic effects of in utero exposure. Stilboestrol affects the Müllerian duct system, leading to abnormalities of the uterus, cervix, and upper vagina. Benign structural anomalies of the cervix and vagina (collars, rims, cockscomb cervix, and pseudopolyps) are found in $25-40 \%$ of women exposed to stilboestrol. ${ }^{78}$ Colposcopy shows epithelial changes in the vagina and cervix in $65-90 \%,{ }^{9}$ with vaginal adenosis (the presence of glandular epithelium in the vagina) being present in $30-75 \% .^{10} \mathrm{With}$ time this glandular epithelium is replaced by squamous epithelium by a process of squamous metaplasia. As in the non-exposed population, this process may become abnormal, resulting in cervical and vaginal intraepithelial neoplasia. Reported rates of cervical and vaginal intraepithelial neoplasia in women exposed to stilboestrol vary widely. ${ }^{910}$ A multicentre study in 1984 found a twofold increase in the incidence of cervical intraepithelial neoplasia among these women. " Currently there is no evidence of an increased incidence of invasive squamous carcinoma in women exposed to stilboestrol.

The risk of clear cell adenocarcinoma of the vagina is low, being about one per 1000 women exposed in utero. Of 519 patients with this carcinoma registered in the United States up to $1985,60 \%$ had documented proof of exposure to stilboestrol, of whom $91 \%$ were 15 to 27 years old. ${ }^{12}$ Though most cases present with vaginal bleeding or discharge, cases diagnosed by screening asymptomatic exposed women have been reported. ${ }^{13}{ }^{1+}$ Prognosis is related to the stage of disease at diagnosis. ${ }^{15}$ Three cases of vaginal clear cell adenocarcinoma have been reported in Britain in women exposed to stilboestrol. ${ }^{16-18}$

In 1977 abnormalities of the upper genital tract (most frequently a $\mathrm{T}$ shaped uterus) were described in 40 of 60 women exposed to the drug. ${ }^{19}$ Although no conclusive evidence exists of increased primary infertility in exposed women, ${ }^{2021}$ rates of spontaneous abortion are higher and the risks of ectopic pregnancy and premature labour are increased, and women should be counselled about these risks. ${ }^{2122}$ Hysterosalpingography is unhelpful in predicting the outcome of pregnancy, and the role of cervical cerclage is disputed. ${ }^{23}{ }^{24}$ Despite these problems about four out of five women exposed to stilboestrol who conceive will have at least one live full term birth. ${ }^{21}$

Though most reports are devoted to women exposed to stilboestrol in utero, those for whom the drug was prescribed during pregnancy and their sons were also exposed to the drug. To date, the only significant untoward effect among mothers has been a small increase in the incidence of breast cancer, the relative risk being $1 \cdot 4(95 \%$ confidence interval $1 \cdot 1$ to 1.9$) 20$ years after exposure. ${ }^{25}$ The incidence of benign abnormalities of the genital tract (epididymal cysts, hypoplastic testes, and cryptochidism) in men exposed to stilboestrol in utero is more than three times that in unexposed men. ${ }^{26}$ There have been unconfirmed reports of impaired fertility in men exposed to stilboestrol ${ }^{26}$ but no evidence of an increased risk of cancer.

How should those who have been exposed to stilboestrol be managed? Young women presenting with abnormal vaginal bleeding or excessive vaginal discharge should be examined under anaesthesia. Screening for neoplasia of the genital tract should include inspection, palpation, and cytological and colposcopic examination of the cervix and vagina. Colposcopy 
may be difficult as most women exposed to stilboestrol show some atypical features. ${ }^{10}$ Consequently, unless the colposcopist is familiar with the problems of exposure there is a tendency to overtreat these women. Caution is recommended in applying locally destructive measures for cervical intraepithelial neoplasia as up to three quarters of affected women will develop cervical stenosis. ${ }^{27}$ Most women require annual colposcopy, with more frequent examination required in the presence of dysplastic change. No studies have been published concerning contraception in women exposed to stilboestrol. Lacking definite data, some physicians prefer not to prescribe hormonal contraceptives,,$^{28}$ and as these women are already at risk of an impaired outcome of pregnancy avoiding using intrauterine contraceptive devices seems prudent.

In Britain stilboestrol was probably last prescribed in pregnancy in 1973. How relevant is this topic today? Many of those who were exposed in utero are now aged between 20 and 35 . They have reached the reproductive phase of their lives and also the time when they are at most risk of cervical intraepithelial neoplasia. Whether in utero exposure to stilboestrol has any consequences for women entering the menopause and postmenopausal years is not yet known.

More generally, the stilboestrol story has important implications for clinical pharmacology and, in particular, for the use of drugs in pregnancy. It shows, if any further demonstration were needed, the absolute necessity for properly performed clinical trials-assessing both efficacy and long term side effects - before the introduction of any new treatment.

Registrar in Obstetrics and Gynaecology,

MARY WINGFIELD

National Maternity Hospital,

Dublin 2

1 Dodds EC, Goldberg L, Lawson W, Robinson R. Oestrogenic activity of certain synthetic compounds. Nature 1938:141:247.
Smith OW. Diethylstilbestrol in the prevention and treatment of complications of pregnancy. Am f Obstet Gynecol 1948;56:821-34.

Herbst AL, Ulfelder H, Poskanzer DC. Adenocarcinoma of the vagina. Association of maternal stilboestrol therapy with tumour appearance in young women. N Engl f Med 1971;284:878-81.

Greenwald P, Barlow JJ, Nasca PC, et al. Vaginal cancer after maternal treatment with sunthetic estrogens. N Engl F Med 1971;285:390-2.

Stillman RJ. In utero exposure to diethylstilbestrol: adverse effects on the reproductive tract and reproductive

6 Kinte $\mathrm{J}$. Badraces pren LJ, Ba in in young people in England and Wales. F Obstet Gynaecol Br Commonwlth 1974;81:849-55.

7 Jeffries JA, Stanley JR, O'Brien PC, et al. Structural anomalies of the cervix and vagina in women enrolled in the diethylstilbestrol adenosis (DESAD) project. Am $\mathcal{F}$ Obstet Gynecol 1984;148: $59-66$

8 Bibbo M, Gill WB, Azizi F, et al. Follow-up study of male and female offspring of DES-exposed mothers. Obstet Gynecol 1977;49:1-8

Stafl A, Mattingly RF. Vaginal adenosis: a precancerous lesion? Am $\mathcal{f}$ Obstet Gynecol 1974;120: 666-77.

10 Herbst A, Scully RE, Robboy SJ. Problems in the examination of the DES-exposed female. Obstet Gynecol 1975;46:353-5.

11 Robboy SJ, Noller KL, O'Brien P, et al. Increased incidence of cervical and vaginal dysplasia in 3980 diethylstilbestrol-exposed young women. FAMA 1984;252:2979.

12 Melnick S, Cole PHP, Anderson D, Herbst A. Rates and risks of diethylstilbestrol-related clear-cell adenocarcinoma of the vagina and cervix - an update. $N$ Engl 7 Med 1987;316:514-6.

13 Kramer MS, Seltzer V, Krumholz B, et al. Diethylstilbestrol-related clear-cell adenocarcinoma in women with initial examinations demonstrating no malignant disease. Obstet Gynecol women with $1984 ; 69: 868-71$.

14 Anderson B, Watzing WG, Edinger JRDD, et al. Development of DES-associated clear-cell carcinoma: the importance of regular screening. Obstet Gynecol 1979;53:293-9.

15 Herbst AL, Robboy SJ, Scully RE, et al. Clear-cell adnocarcinoma of the vagina and cervix in girls: analysis of 170 reported cases. Am $\mathcal{F}$ Obstet Gynecol 1974;119:713

6 Monaghan JM, Sirisena LAW. Stilboestrol and vaginal clear-cell adenocarcinoma syndrome. $B M J$ 1978;i: $1588-90$

7 Dewhurst J, Ferreira HP, Dalley VM, Staffurth JM. Stilboestrol-associated vaginal carcinoma treated by radiotherapy. F Obstet Gynecol Neonatal Nurs 1980;1:63-4.

18 Davis JA, Wadehra V, McIntosh AS, Monaghan JM. A case of clear-cell adenocarcinoma of the vagina in pregnancy. Br f Obstet Gynaecol 1981;88:322-6.

19 Kaufman RH, Binder GL, Gray PM, Adam E. Upper genital tract changes associated with in-utero exposure to diethylstilbestrol. Am $\mathcal{F}$ Obstet Gynecol 1977;128:51.

20 Senekjian EK, Potkul RK, Frey K, Herbst A. Infertility among daughters either exposed or not exposed to diethylstilbestrol. Am f Obstet Gynecol 1988;158:493-8.

21 Barnes AB, Colton T, Gundersen J, et al. Fertility and outcome of pregnancy in women exposed in utero to diethylstilbestrol. N Engl f Med 1980;302:609-13.

22 Sandberg EC, Riffle NL, Higdon JV, Gertman CE. Pregnancy outcome in women exposed to diethylstilbestrol in utero. Am f Obstet Gynecol 1981;140:194-205.

diethylstilbestrol in utero. Am F Obstet Gynecol 1981;140:194-205.
Ludmir J, Landon MB, Gabbe SG, et al. Management of the diethylstilbestrol-exposed pregnant patient: a prospective study. Am F Obstet Gynecol 1987;157:665-9.

24 Michaels WH, Thompson HO, Schreiber FR, et al. Ultrasound surveillance of the cervix during pregnancy in diethylstilbestrol-exposed offspring. Obstet Gynecol 1989;73:230-9.

25 Greenberg $\mathrm{AB}$, Barnes $\mathrm{L}$, et al. Breast cancer in mothers given diethylstilbestrol in pregnancy. $N$ Engl f Med 1984;311:1393-8.

26 Gill WB, Schumacher GFB, Bibbo M, et al. Association of diethylstilbestrol exposure in utero with cryptorchidism, testicular hypoplasia or semen abnormalities. F Urol 1979;122:36.

27 Schmidt G, Fowler WC. Cervical stenosis following minor gynaecological procedures on DES-exposed women. Obstet Gynecol 1980;56:333-5.

28 Guidelines for the management of the DES-exposed. 1983: State of California Health and Welfare Agency, Department of Health Services.

\section{Eye injuries in racquet sports}

\section{Proper protection needed}

The causes of serious eye injury (requiring admission to hospital) have changed dramatically over the past 70 years. ${ }^{1}$ In the 1920s occupational injuries predominated; by the 1970 s road traffic accidents were becoming more important. Protective measures, including the Factories Act 1961, the Protection of Eyes Regulations 1974, seatbelt legislation, and the adoption of laminated windscreens reduced the incidence of eye injuries from these causes. Severe eye injuries from road traffic accidents are now uncommon, ${ }^{3-5}$ and work related eye injuries are rarely serious.

The pattern of trauma continues to change. In the 1980s more participation in sport resulted in a predictable increase in the numbers of injuries. Only $0.7 \%$ of severe eye injuries were sustained at sport in 1909-13. ${ }^{1}$ By 1967-76 the figure had risen to $4 \cdot 1 \%{ }^{2}$ by 1987 it was $25 \cdot 1 \%,{ }^{6}$ and by $1989,42 \cdot 2 \%{ }^{5}$ Sport is now indisputably the commonest cause of a serious eye injury in Britain, which seems to be rising in incidence. In addition, patients presenting with eye injuries associated with sports are more likely to have sustained sight threatening trauma than those with any other cause of injury, ${ }^{5}$ and almost half of those requiring admission to hospital suffer some permanent reduction in visual performance. ${ }^{6}$

Penetrating injury is seen only rarely in sport and is usually associated with the inappropriate use of glass spectacles. More typical is a severe blunt injury caused by a blow from a ball, racquet, fist, or elbow. Mostly this results in intraocular haemorrhage. Many patients will have permanently damaged pupils and may later develop chronic glaucoma. The lens may be damaged, either by opacification or dislocation. Retinal breaks and detachment are sometimes seen, as are ruptures of the choroid and haemorrhagic oedema (commotio) of the macula. Any injury to the retina or choroid is potentially blinding. Blowout fractures of the floor or medial wall of the orbit are not uncommon and may result in diplopia or cosmetic problems. Fortunately, rupture of the globe from a high energy blow is rare; loss of the eye usually follows.

The immediate management of a severe blunt eye injury is conservative. An attending doctor without specialised equipment should simply exclude or confirm serious eye injury and transfer the patient to an accident and emergency department safely and quickly, with the eye padded. The patient may be shocked and may vomit, and the possibility of an associated head injury should be borne in mind. Attempting ocular examination within a few minutes of the injury is probably unwise. The eyelids should not be forced open. When possible an estimate of vision should be obtained. Using good 